\title{
Gone Global: Familiar and Exotic Cucurbits Have Asian Origins
}

\author{
James D. McCreight ${ }^{1}$ \\ U.S. Department of Agriculture, Agricultural Research Service, U.S. Agricultural Research Station, \\ 1636 E. Alisal Street, Salinas, CA 93905
}

Jack E. Staub

U.S. Department of Agriculture, Agricultural Research Service, Forage and Range Research Laboratory, Utah State University, Logan, UT 84322-6300

Todd C. Wehner

Department of Horticultural Science, North Carolina State University, P.O. Box 7609, Raleigh, NC 27695-7609

\author{
Narinder P.S. Dhillon \\ AVRDC-The World Vegetable Center, East and Southeast Asia, P.O. Box 1010 (Kasetsart), \\ Bangkok 10903, Thailand
}

\begin{abstract}
Additional index words. Citrullus lanatus, Cucumis hystrix, Cucumis melo, Cucumis sativus, germplasm, grafting, host plant resistance, Momordica charantia
\end{abstract}

Cucurbits comprise the highly diverse family known as Cucurbitaceae that includes cultivated, feral, and wild species (Robinson and Decker-Walters, 1997). Many of the cultivated species such as squash (Cucurbita ssp.), watermelon [Citrullus lanatus (Thunb.) Matsum. \& Nakai], cucumber (Cucumis sativus L.), and melon (Cucumis melo L.) are familiar to U.S. and world markets. Others such as bitter gourd (Momordica charantia L.) are less familiar in the United States. Cucurbits are cultivated more broadly than any other vegetable species after tomato, Solanum lycopersicum L. (<http://faostat.fao.org $>)$.

Cucurbits exhibit great genetic diversity expressed phenotypically in vegetative, e.g., plant architecture and growth habit, floral, e.g., sex expression, and fruit characters that include size, shape, skin texture, exterior and interior colors, sweetness and flavor, and postharvest shelf life. They are especially known for their fruit, which may be consumed fresh, cooked or baked, dried, or processed (Robinson and Decker-Walters, 1997). Immature or mature fruit are, depending on the species, consumed as fresh or cooked vegetables. Melon and watermelon are especially well known

Received for publication 27 Feb. 2013. Accepted for publication 17 June 2013.

USDA is an equal opportunity provider and employer. Mention of trade names or commercial products in this publication is solely for the purpose of providing specific information and does not imply recommendation or endorsement by the U.S. Department of Agriculture.

This paper was part of the workshop "Good Genes from Asia-Contributions and Opportunities of Asiatic Origin Crops to U.S. Horticulture" held 3rd Aug. 2012 at the ASHS Conference, Miami, $\mathrm{FL}$, and sponsored by the Working Group of Asian Horticulture and The Association of Horticulturists of Indian Origin.

${ }^{1}$ To whom reprint requests should be addressed; e-mail jim.mccreight@ars.usda.gov. for their sweet, flavorful, and colorful fruit that are usually eaten fresh but may be processed in confections or jams (Fig. 1).

Cucurbit seeds are edible fresh (Anon., 2012c) or dried (Fig. 1). They are a source of high-quality vegetable oil (Fig. 1) and the expressed meal is high in edible protein (Jacks et al., 1972). Roots (Gathman and Bemis, 1990) and leaves (Jensen, 2012) of some species may also be used for industrial or culinary purposes.

Asia and cucurbits are intertwined. Origins of the many members of the Cucurbitaceae have been of great interest for $100+$ years, some regarded as Old World (Asia and Africa), whereas others are regarded as New World (the Americas) species (for a somewhat dated overview, see Esquinas-Alcazar and Gulick, 1983). Recent analyses indicate, however, an Asian origin of the family Cucurbitaceae and numerous oversea dispersal events (Schaefer et al., 2009).

India and Southeast Asia, including China, comprise the primary and secondary centers of diversity, respectively, of cucumber. India and central and southwest Asia comprise the primary center of diversity for melon with China as a secondary center of diversity (Esquinas-Alcazar and Gulick, 1983). India and Africa are primary centers of watermelon and related species (Esquinas-Alcazar and Gulick, 1983). Melon and cucumber likely moved westward overland through central Asian trade routes, collectively referred to as the Silk Road (Wild, 1992) through central Asia and the Middle East to Europe and Africa and from there onto the New World. In contrast, the center of diversity for watermelon is in Africa (Esquinas-Alcazar and Gulick, 1983); it is thought that cultivated watermelon moved from there to Asia. The center of diversity of bitter gourd is the Old World tropics with its highest diversity in India, China, and Southeast Asia (EsquinasAlcazar and Gulick, 1983). Bitter gourd likely arrived in the United States with Chinese immigrants in the 18th century.

Seedless (tetraploid) watermelon, the product of an early 20th century discovery in Japan, entered the U.S. marketplace at the end of that century, where it quickly gained popularity when bred into a small fruit size background and adapted to U.S. growing conditions. Grafting of watermelon onto disease-resistant rootstocks was developed during the 1920 s in Japan and Korea (Davis et al., 2008). This technology holds great promise for melon and watermelon production in the United States as the use of methyl bromide and other soil fumigants become more restricted (Davis et al., 2008).

New resources, i.e., crop germplasm, and technology, e.g., tetraploidy and grafting, contribute to sustainable crop productivity (Day, 1997). We provide an overview of the positive impact of Asian cucurbit germplasm and technology on U.S. melon, cucumber, and watermelon production and the potential for bitter gourd, a relatively new commercial crop in the United States with many useful attributes.

\section{MELON}

Domestication of melon may have occurred independently in southeast Asia, India, and East Asia (Esquinas-Alcazar and Gulick, 1983; Pitrat, 2012). Today, the primary center of melon diversity is in southwest and central Asia (Turkey, Syria, Iran, Afghanistan, north and central India and Transcaucasia, Turkmenistan, Tajikistan, and Uzbekistan) with secondary centers of diversity in China, Korea, and the Iberian Peninsula (Esquinas-Alcazar and Gulick, 1983).

Genetic diversity of Chinese, Indian, Japanese, and Turkish melon germplasm has been characterized using isozyme and molecular markers (Akashi et al., 2002; Dhillon et al., 2007, 2009; Fergany et al., 2011; Kaçar 


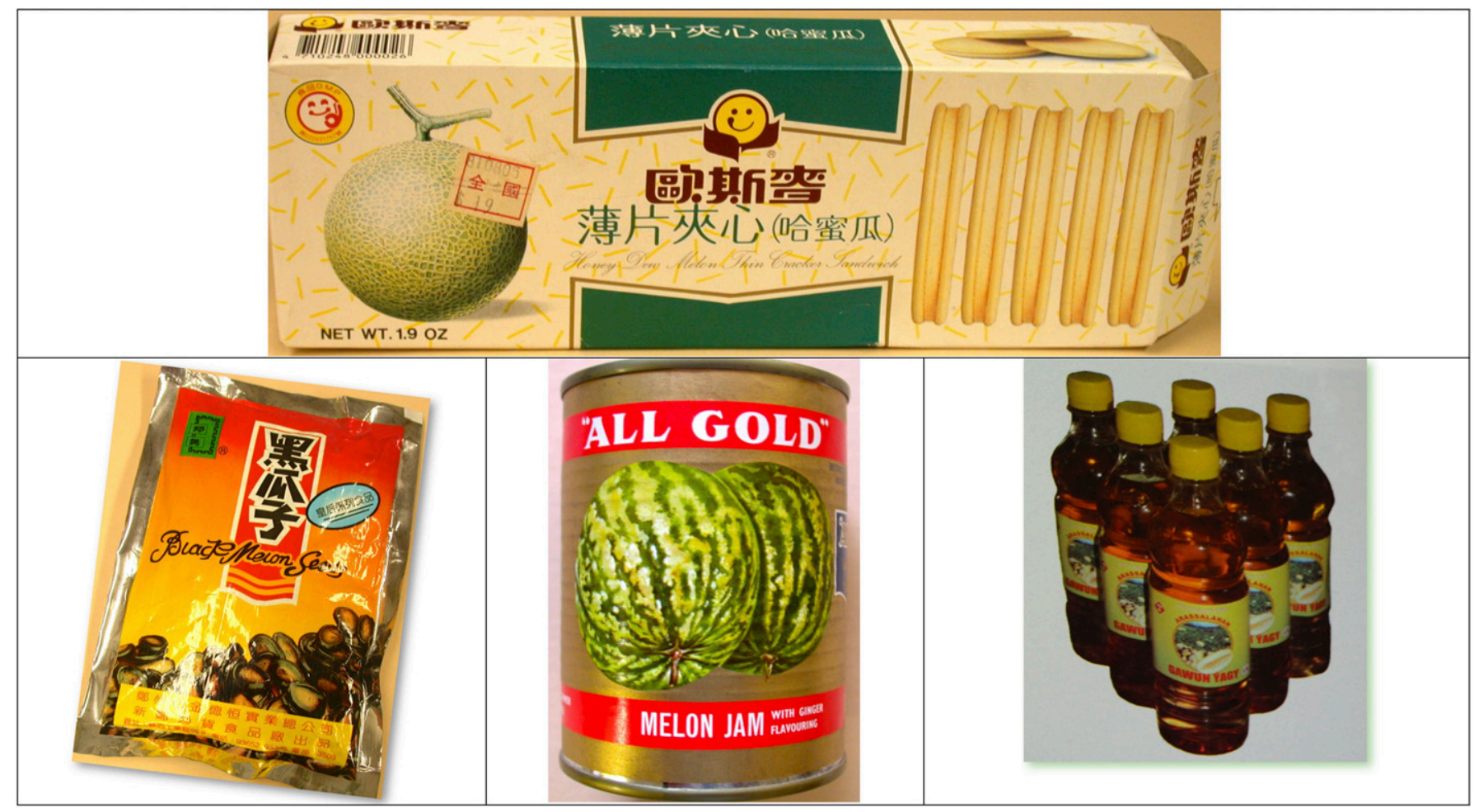

Fig. 1. Examples of processed melon (C. melo) and watermelon (Citrullus lanatus) fruit. Top, flavoring of cookies in China (C. melo ssp. melo Reticulatus group). Bottom, from left to right: roasted watermelon seeds in China, watermelon jam in the Republic of South Africa, and melon seed oil in Turkenistan. All photos courtesy of J.D. McCreight except seed oil (Anon., 2008).

et al., 2012; Luan et al., 2008; McCreight et al., 2004; Nakata et al., 2005; Roy et al., 2012; Tzuri et al., 2005). Studies indicate that Asian melon germplasm was used in the development of the melon genome (Garcia-Mas et al., 2012). The great diversity within melon has been systematically organized numerous times by different investigators in various parts of the world using different and often incomplete samples of the diversity (Pitrat et al., 2000). The most recent reviews of melon genetic diversity and domestication are in agreement on the organization of the botanical groups of the two subspecies of melon, C. melo ssp. agrestis, with five groups, and C. melo ssp. agrestis, with 10 (Pitrat, 2008) or 11 (Burger et al., 2010) groups (Table 1). There are many landraces, farmer selections, and cultivars within these groups. Because they are fully compatible sexually, intermediate types can be found and will likely increase as breeders seek new combinations of traits from two or more of the botanical groups (Dhillon et al., 2012; Pitrat, 2012).

Melons moved from India to central Asia, China, the Middle East, and Europe. The timeline for movement of melons to these areas is unknown, but a recent study of ancient manuscripts, the Hebrew Bible, and images from antiquity document the culture and uses of non-sweet melons in the Chate and Flexuosus groups as early as 1350 B.C. (Janick et al., 2007). Literature from Roman and medieval periods revealed that sweet melons were known in central Asia in the mid-9th century, Khorasan (Turkmenistan, Uzbekistan Afghanistan, Tajikistan, and northeastern Iran) and Persia by the mid10th century, and in Andalusia (Spain) by the mid-11th century (Paris et al., 2012). These areas still to this day have a wealth of genetically diverse melon germplasm (Anon., 2008; Escribano et al., 2012; Esquinas-Alcazar, 1981; Mavlyanova et al., 2005a; McCreight et al., 2010).

Current melon cultivars in the United States can be traced to European and Asian (China, India, and Japan) introductions (Tapley et al., 1937; Whitaker and Davis, 1962). Europeans undoubtedly first introduced melons to the Americas. Tapley et al. (1937) stated that melons were reportedly grown by Native Americans as early as 1535 and that "...13 sorts..." of melons were listed in one catalog dated 1806, " ....all of which were from the Old World and accounts of which are included in European literature." Nearly 300 popular and obscure muskmelon varieties (C. melo ssp. melo Reticulatus group) were known in the United States by 1937, and many of them had numerous synonyms, e.g., 51 for 'Rocky Ford' (Tapley et al., 1937). Current descriptions and photographs of many of the varieties described by Tapley et al. (1937) are included in Melons, for the Passionate Grower (Goldman and Schrager, 2002).

At the time Tapley et al. (1937) were preparing their list of muskmelon varieties, 'Powdery Mildew Resistant No. 45', or 'PMR 45' (C. melo ssp. melo Reticulatus group) as it is most widely known, was released (Jagger and Scott, 1937). 'PMR 45' is likely the first melon cultivar intentionally selected for
Table 1. Botanical groups of melon grouped by fruit type and sub-species. ${ }^{\mathrm{z}}$

\begin{tabular}{lll}
\hline & \multicolumn{2}{c}{ Sub-species } \\
\cline { 2 - 3 } Fruit type & \multicolumn{1}{c}{ agrestis } & \multicolumn{1}{c}{ melo } \\
\hline Non-sweet & Acidulus & Chate \\
& Conomon & Chito $^{\mathrm{y}}$ \\
& Momordica & Flexuosus \\
& & Tibish \\
Sweet & Makuwa & Adana \\
& Chinensis & Ameri \\
& & Cantalupensis \\
& & Chandalak \\
& & Reticulatus \\
& & Inodorus \\
Fragrant & & Dudaim \\
\hline
\end{tabular}

${ }^{\mathrm{z}}$ Based on Burger et al. (2010) and Pitrat (2008).

${ }^{\mathrm{y}}$ Not included in Pitrat (2008).

disease resistance in a scientific program of screening exotic germplasm (of Indian origin), crossing of resistant germplasm with susceptible germplasm, and subsequent controlled pollination with one backcross generation and selection for resistance and horticultural type. In this case, the powdery mildew-susceptible, orange flesh 'Hale's Best' muskmelon (C. melo ssp. melo Reticulatus group; Tapley et al., 1937) was crossed with Calif. 525 (C. melo ssp. agrestis Momordica group), which was a self-pollinated increase of an Indian melon named 'Big Round' that was brought to the United States by an Indian student of J.T. Rosa (I.C. Jagger, unpublished pedigree note). Their $\mathrm{F}_{1}$ was resistant to cucurbit powdery mildew (CPM) incited by Podosphaera xanthii (Jagger and Scott, 1937; McCreight, 2004) and was self-pollinated to 
produce the $\mathrm{F}_{2}$ progeny. A CPM-resistant $\mathrm{F}_{2}$ selection was backcrossed to 'Hale's Best' to recombine CPM resistance with the horticultural qualities of 'Hale's Best'. Seven generations of inbreeding and selection resulted in 'PMR 45' (Jagger and Scott, 1937; Pryor et al., 1946). This cultivar redefined the western U.S. orange flesh shipper-type melon. Calif. 525 was a source of CPM resistance as well as heat and salt tolerance (Shannon et al., 1984; Whitaker, 1979).

The most common forms of melon in the United States are the muskmelon, commonly referred to in the United States as "cantaloupe," (C. melo ssp. melo Reticulatus group) and honeydew (C. melo ssp. melo Inodorus group). The so-called "mixed melons" that are often present in many mainstream U.S.

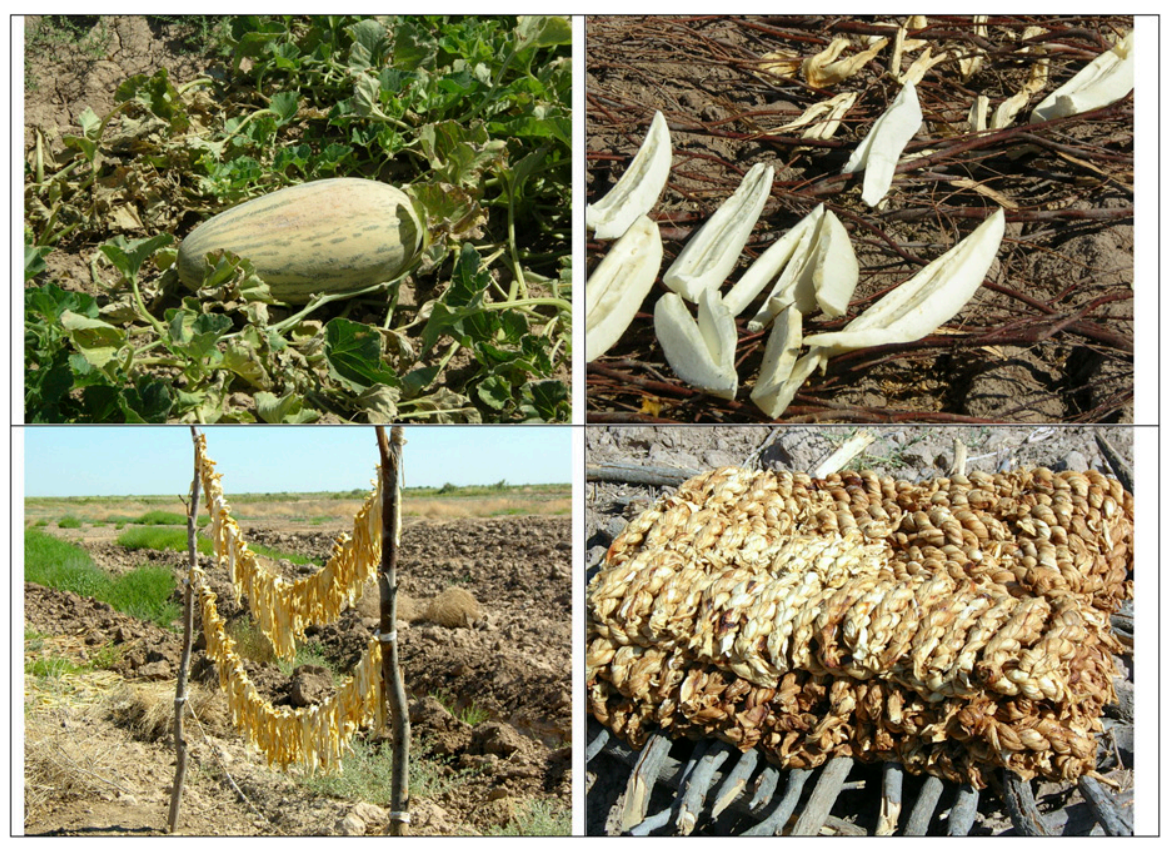

Fig. 2. "Gavun kak" is a dried form of melon (C. melo ssp. melo Inodorus group) for consumption when fresh melons are not readily available in central Asia. Clockwise from top left: Waharman-type melon; strips of the flesh are dried first on a bed of brush and then suspended on strings and finally twisted together for packing and sale. All photos courtesy of J.D. McCreight.

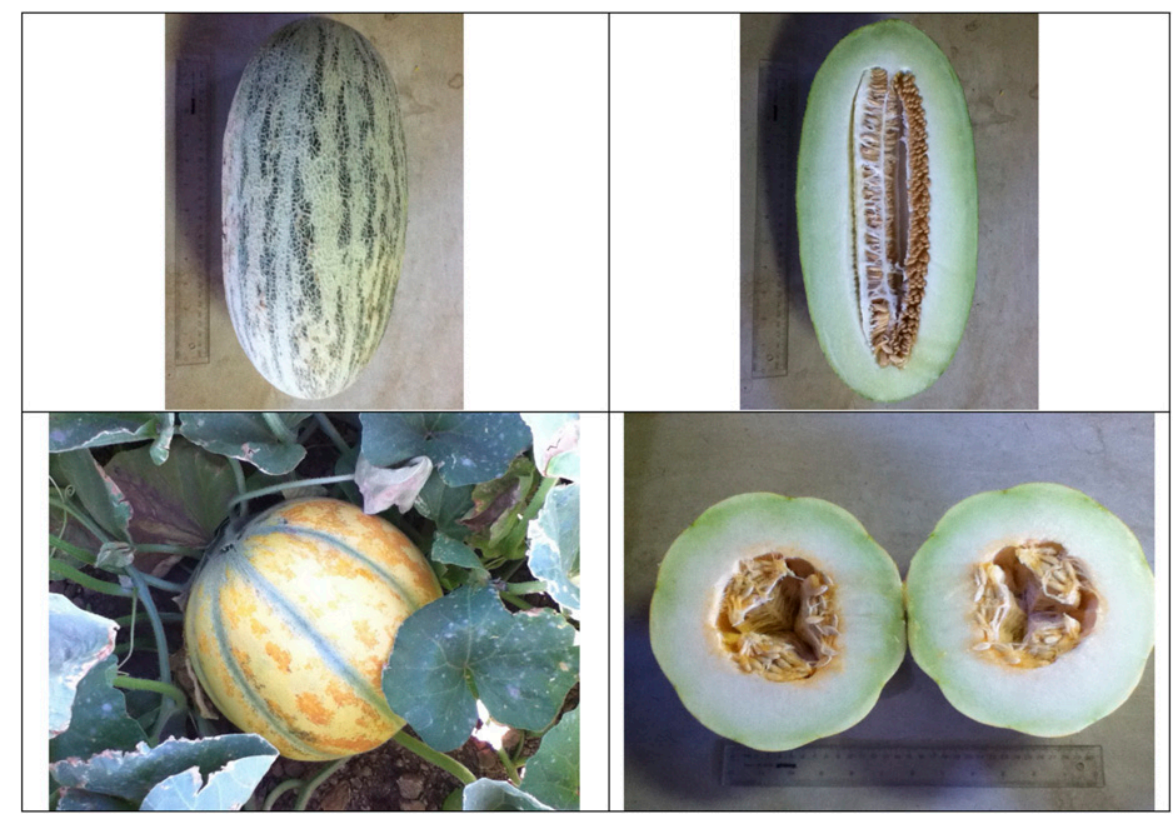

Fig. 3. Fruit of Turkmen melons (C. melo ssp. melo) grown in Imperial Valley, CA, on 6 June 2012, 90 d post-planting. Top, unripe sample of 'Gyzyl Waharman 1' (Inodorus group), $4.8 \mathrm{~kg}$ and 10.1\% soluble solids (SS). Bottom, ripe sample of 'Turkman Zamcha' (Ameri group), $2.3 \mathrm{~kg}$ and $12.9 \% \mathrm{SS}$. All photos courtesy of J.D. McCreight.

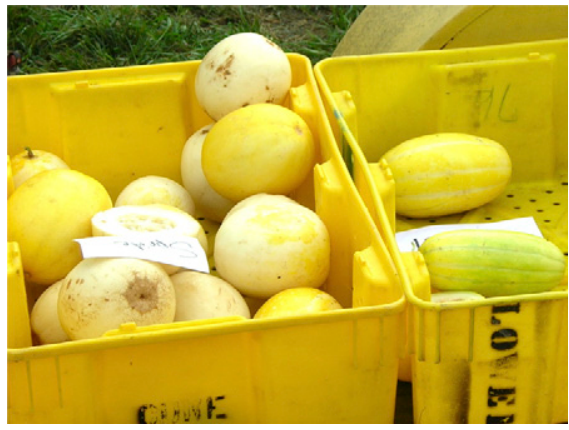

Fig. 4. Melon (C. melo) fruits grown in North Carolina. Left bin, 'Sprite' (ssp. agrestis Makuwa group); right bin, Korean melon (ssp. agrestis Makuwa group). Photo courtesy of J.D. McCreight.

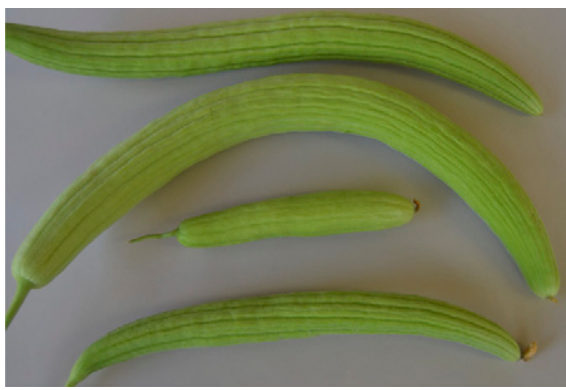

Fig. 5. Snakemelon fruits (C. melo ssp. melo Flexuosus group) grown in a greenhouse, Salinas, CA. Photo courtesy of J.D. McCreight.

HortScience Vol. 48(9) September 2013 
Table 2. Disease, insect and nematode resistances, and abiotic stress tolerances described in Indian melon germplasm (Dhillon et al., 2012).

\begin{tabular}{ll}
\hline Category & \multicolumn{1}{c}{ Species or common name, } \\
or abiotic stress
\end{tabular}

characters and random amplified polymorphic DNA and simple sequence repeat markers (Decker-Walters et al., 2002).

Many accessions from India have been found to have genes for resistance to one or more of six fungal pathogens and 13 viruses, seven insect species, and three nematode species and tolerance to salinity, high temperatures, and drought (Dhillon et al., 2012), although not all have been used in breeding melons for the United States (Table 2). In addition, 38 genes and quantitative trait loci for seedling, vegetative, flower and fruit traits, and isozymes have been described in 21 accessions or in offspring from crosses with one or more involving Indian melon accessions (Dhillon et al., 2012).

Twenty-seven Asian, mostly Indian, melon accessions are of special interest to U.S. melon breeding and production (Table 3 ). Numerous publicly developed selections (to stabilize resistance), breeding lines, and cultivars have been bred from nine of them for the various melon-producing regions of the United States, although genes from many have yet to be transferred to U.S. cultivars. Genes for powdery mildew resistance in Calif. 525, PI 79376, and PI 124112 were transferred to 14 breeding lines and cultivars (Harwood and Markarian, 1968) and are still important in modern releases. The pedigree of breeding line PMR Honeydew includes Calif. 525, PI 79376 (through Resistant Cantaloupe), and
PI 124111 (C. melo ssp. agrestis Momordica group) (McCreight et al., 1987). 'Chujuc' $(C$. melo ssp. melo Reticulatus group) and 'Pacal' (C. melo ssp. melo Inodorus group) are recently released cultivars adapted to Texas with these genes (Crosby et al., 2007, 2008). 'PMR Delicious 51' (C. melo ssp. melo Reticulatus group) is a recently released Bender-type melon for the northeast and, possibly, the northwest United States (Henning et al., 2005a; Tapley et al., 1937; Whitaker and Bohn, 1956). Commercial breeders have developed more cultivars, including $\mathrm{F}_{1}$ hybrids (McCreight, 2007). One additional accession, PI 157083 (C. melo ssp. agrestis Chinensis or Makuwa group), from China, is of interest as a seedling marker for a unique, single recessive gene that conditions a photosensitive red pigmentation under the epidermis of stems, especially at nodes, and reddish or tan seed color (McCreight and Bohn, 1979). The unidentified pigment is obvious in the stems early each morning but fades quickly through the day, and by the next morning, the pigment intensity has been restored.

Asian melon germplasm continues to be introduced to the United States as specialty melons to meet the demands of specific émigré communities. Hami melons ( $C$. melo ssp. melo Inodorus group) from the Xinjiang Province in western China include a range of shapes and epidermis and flesh colors (Anon., 2003). 'Honey Kiss Hami Gold' grown in Arizona and California is available from May through November (Anon., 2012a). 'Sprite' (Fig. 4), which was introduced into the United States from Japan, produces a small, oblong fruit with cream epidermis and firm, white flesh that is very sweet to the taste (up to $\left.18^{\circ} \mathrm{Brix}\right)$ and is shipped by North Carolina growers from June through September (Anon., 2012b). 'Sprite' has become a popular specialty melon for growers in several southeastern states (Anon., 2012d; Schultheis, 2006).

Korean or Oriental melons (C. melo ssp. agrestis Makuwa group) are similar to 'Sprite' but have bright to light yellow epidermis and prominent although shallow, whitish vein tracts (Fig. 4) (Davis, 1970). The entire fruit, rind, and seeds are edible (Anon., 2012c). Korean melons are commercially grown in California and Mexico for U.S. consumption (Anon., 2010).

Melons from central Asia (C. melo ssp. melo Ameri and Inodorus groups) have promise for local or regional farmers markets in California and Arizona, which have similar growing conditions and long seasons similar to those found in Uzbekistan and Turkmenistan (Molinar, 2012). Uzbek and Turkmen melon varieties come in a wide range of sizes $(0.5$ to $17.0 \mathrm{~kg}$ ) with sugar levels that range up to $25 \%$ under ideal conditions and shelf lives from very short (for local markets) to 7 months (Fig. 3) (Anon., 2008; Mavlyanova et al., 2005a, 2005b; McCreight et al., 2010).

\section{CUCUMBER}

India and southeast Asia constitute the primary center of diversity for cucumber, which was domesticated $\approx 3000$ years ago (Dane et al., 1980; Esquinas-Alcazar and Gulick, 1983; Jeffrey, 1980). Cucumis sativus houses several cross-compatible botanical varieties including var. sativus, the cultivated cucumber (hereafter referred to as $C$. s. var. sativus), and the wild, free-living var. hardwickii (R.) Alef., hereafter referred to as $C$. s. var. hardwickii (Kirkbride, 1993). Cucumis s. var. hardwickii is considered a feral form of C. s. var. sativus that grows in the foothills of the Himalayan mountains and is used by native people of northern India as a laxative (Deakin et al., 1971). This botanical variety presents extreme variation from typical cucumber in two Indian accessions, PI 183967 (syn. LJ 90430) from Meghalaya and PI 215589 from Uttar Pradesh (Dijkhuizen et al., 1996) and, thus, has potential for increasing genetic diversity in commercial cucumber (Staub and Kupper, 1985; Staub et al., 1992).

The wild, free-living $C$. hystrix is sparingly cross-fertile with cucumber and is found in the Yunnan Province of southern China (Chen et al., 1995, 1997), but fertile amphidiploids synthesized from a $C$. hystrix $\times C$. $s$. var. sativus cross resulted in a synthetic species called C. hytivus (Chen and Kirkbride, 2000; Chen et al., 1997; Sebastian et al., 2010). Furthermore, the development of the fully fertile $C$. hytivus-derived fertile diploids $(2 n=2 x=14 ; \mathrm{SS})$ from $C$. hytivus $\times C$. $s$. var. sativus crosses resulted in potentially useful germplasm for plant improvement (Staub and Delannay, 2011). The incorporation of genes from the secondary gene pool of cucumber such as $C$. hystrix is potentially useful to cucumber breeding given that $C$. hystrix possesses novel genes for disease resistance, e.g., gummy stem blight (Didymella bryoniae), that are not present in cultivated cucumber (Chen et al., 2003). Backcrossing with concurrent initial molecular-based genotyping and selection for genetic diversity in $C$. sativus $\times C$. hystrix-derived populations increased genetic diversity (phenotypic and genotypic) in cucumber (Delannay et al., 2010) and resulted in the development of 94 inbred backcross lines (IBLs) from the second backcross to cucumber $\left[\mathrm{S}_{3} \mathrm{BC}_{2}(C\right.$. sativus $\times C$. hytivus) $C$. sativus] for use in cucumber improvement (Staub and Delannay, 2011). The genetic distance (GD) between parental lines (C. sativus and C. hytivus) was 0.85 , and the GD between the 94 IBLs ranged between 0.16 and 0.75 . These IBLs differ in days to flower, sex expression, lateral branch number, number of fruits per plant, and fruit length and diameter ratio. Although the performance of these IBLs are predicted to differ depending on growing environment, strategic crossing of these IBLs with elite lines may allow for the development of broad- and narrow-based populations using phenotypic and/or marker-assisted selection (Fan et al., 2006).

The $1400+C$. s. var. sativus and var. hardwickii accessions currently resident in the U.S. National Plant Germplasm System (USDA, ARS, North Central Regional Plant 
Introduction Station, Ames, IA) represent the primary cucumber gene pool. The secondary gene pool of $C$. sativus includes crossincompatible, e.g., wild African species, or sparingly cross-compatible, e.g., C. hystrix, species (Chen et al., 1997; Chung et al., 2006). The tertiary gene pool of cucumber consists of distantly related species from other genera or sub-genera, e.g., Cucumis melo L. and Cucurbita L., which do not hybridize with cucumber (Chung et al., 2006; Staub et al., 1987). Attempts to exploit resources beyond the primary cucumber gene pool, e.g., Cucumis metuliferus, C. melo, have either been unsuccessful or unrepeatable.

Assessments of genetic diversity in $C$. $s$. var. sativus and var. hardwickii using isozymes, restriction fragment length polymorphisms, and random amplified polymorphic DNA indicate that diversity in C. s. var. sativus is relatively low (3\% to $8 \%$ ) when compared with other cross-fertilized species of Cucumis (10\% to $25 \%$ ) (Dijkhuizen et al., 1996; EsquinasAlcazar, 1977; Horejsi and Staub, 1999). Polymorphism level in C. s. var. hardwickii ( $17 \%$ to $25 \%$ ) is predictably higher than C. s. var. sativus (Dijkhuizen et al., 1996; Horejsi and Staub, 1999). Furthermore, genetic diversity analysis indicates that Indian and Chinese cucumbers differ substantially (Staub et al., 1999) and that C. s. var. Xishuangbannanesis (possesses an orange endocarp high in carotenoids) accessions from the Yunnan Province, China, are unique based on their pedigree, nutritional attributes, and restricted production range (Simon and Navazio, 1997). Genetic variation in Chinese accessions high in carotenoid pigment variation (orange color) has been incorporated into U.S. processing cucumber germplasm to improve human health (Staub et al., 2011a).

Cucumber is typically eaten fresh, i.e., fresh or slicing market types, or as a processed product (processing or pickling types) (Staub and Bacher, 1997; Staub et al., 2008). The major fruit types are the American processing and fresh market types, the Dutch gherkin and greenhouse types, the German Schalgurken type, the Mid-East Beit Alpha type, and the Oriental trellis (burpless) type. Fresh market types are grown in fields or greenhouses and are 15 (U.S. and Mediterranean) to 40 (European) $\mathrm{cm}$ in length. Sfran (compact fruit types marketed in the Persian Gulf) and "lemon" cucumber (shape similar to a lemon with pale, greenish yellow skin; hermaphroditic) are less common fresh market types.

Gherkin cucumber (C. s. var. sativus) is a tiny immature cucumber used for pickling. Harvest of gherkins is labor-intensive as a result of their small size, which is generally less than $7.5 \mathrm{~cm}$ long. India has, as a result of the low labor costs, become a major producer of gherkins for export to Europe, the United States, Russia, and other Commonwealth of Independent States. Nearly 60 processing companies in the states of Karnataka, Tamil Nadu, and Maharashtra grow gherkins on $\approx 12,000$ ha. Ajax and Sparta (Nunhems) are currently the dominant cultivars and account for 2.5 billion seeds in India alone (P. Arul
Murugan, IAP Farm Services Pvt. Ltd., Tamil $\mathrm{Nadu}$, India, personal communication, 2012).

Cucumis sativus var. hardwickii, principally PI 183967 and PI 215589, was used in breeding to increase yield in commercial cucumber through new plant architecture, fruiting habit and leaf size (Horst and Lower, 1978; Secre and Staub, 1999; Staub and Kupper, 1985; Staub et al., 1992). Its fruit quality characteristics (bitter, small seedy fruit) and lack of disease resistance have been, however, an impediment to ultimate use in commercial pickling cucumber cultivars (Horst and Lower, 1978; Staub et al., 2008). Nevertheless, potentially useful $C$. s. var. hardwickii-derived germplasm (PI 183967 and PI 215589) has been released. For example, the gynoecious, multiple diseaseresistant, white spine cucumber population WI 6383 and its derived highest yielding lines (WI 5098 and WI 5551) were developed from a $C$. s. var. sativus $\times$ var. hardwickii mating (Staub et al., 1992), but their poor internal characteristics and brining quality have precluded their widespread use in cucumber breeding.

Gynoecious sex expression provides great potential for increased yield. Genes for gynoecy in PI 220860 (Republic of Korea) resulted in the development of MSU 713-5, GY 3, and 'Spartan Dawn' pickling cucumbers (Peterson, 1975).

Resistances to numerous diseases have been transferred from Asian germplasm into U.S. commercial cucumber cultivars: leaf spot from PI 197088 (India), anthracnose from PI 175111 (India), bacterial wilt from PI 200818 (Burma), target leafspot from PI 109484 (Turkey), and powdery and downy mildews from PI 197087 (Assam, India), PI 197085 (Assam, India), and PI 212233 (Japan). Recent acquisitions from China, Japan, Pakistan, Philippines, and Taiwan have complemented the breeding efforts with the older accessions for the incorporation of disease resistance (Block and Reitsma, 2005; Staub et al., 2002).

\section{WATERMELON}

Watermelon was for many years thought to have originated in southern Africa because it was found growing wild throughout the area and reached maximum diversity there. The citron (Citrullus lanatus var. citroides) grows wild throughout southern Africa and may be related to the wild ancestor of watermelon. The secondary center of diversity for watermelon is China. Colocynth (Citrullus colocynthis), a related species, grows wild in India. Areas of the Middle East as well as countries near the Mediterranean Sea may also be good places to collect old landraces and wild accessions of Citrullus. For a review of watermelon, see Wehner (2008).

The colocynth may also be a wild ancestor of watermelon and is now found native in North and West Africa. Fruit of colocynth are small with a maximum diameter of $75 \mathrm{~mm}$. The flesh is bitter and the seeds are small and brown. Crosses of $C$. lanatus with $C$. colocynthis produced $\mathrm{F}_{1}$ hybrids with nearly regular meiosis. The pollen was $30 \%$ to $40 \%$ fertile, and $35 \%$ of the seeds were fertile. The original wild watermelons probably had hard, nonsweet, sometimes bitter, white flesh, similar to the citron and colocynth.

Watermelon has been cultivated in Africa for over 4000 years and was probably brought to the Middle East by humans who domesticated the crop plant for their use as food as well as cattle feed. Watermelon was probably brought to China by way of the Silk Road from the Middle East. Cultivation of watermelon began in ancient Egypt and India and is thought to have spread from those countries through the Mediterranean area, the Near East, and Asia. Central Asia is, as a result, a tertiary center of diversity for watermelon.

Priorities for collection of Citrullus germplasm include India (especially the IndoGangetic plains and areas in the northwest parts of the country), south and southwest Africa (Kalahari Region), the southern areas of the former Soviet Union (Kazakhstan, Uzbekistan, Turkmenistan), Iran, and tropical Africa. Recent work in germplasm collection and exchange has provided the U.S. Dept. of Agriculture (USDA) germplasm system with a total of 51 Citrullus accessions that were collected during a scientist exchange visit with the People's Republic of China in 1994. Later, in 1996, a team of four researchers collected germplasm of Citrullus in the Republic of South Africa. Twenty-two melon landraces were collected in Turkmenistan in 2008 (McCreight et al., 2010).

Several germplasm collections, along with current cultivars marketed by seed companies, represent the major sources of germplasm for watermelon breeders. The USDA collection is stored at the Regional Plant Introduction Station, Griffin, GA, with the backup collection at the National Center for Genetic Resources Preservation (formerly the National Seed Storage Laboratory), Fort Collins, CO. There are 3837 (1538 currently available) accessions in the collection. The collection includes representatives of all Citrullus species and botanical varieties. In addition, $\approx 300$ heirloom cultivars are kept at the National Center for Genetic Resources Preservation.

China is the major producer of watermelon in the world. Consumers there have a preference for red flesh color first but with a large interest in canary yellow as well. Flesh color can be scarlet red, coral red, orange, canary yellow, salmon yellow (golden), or white. Scarlet red $\left(\mathrm{Y}^{\mathrm{Scr}} \mathrm{Y}^{\mathrm{Scr}}\right)$ is dominant to coral red $\left(Y^{C r l} Y^{C r l}\right)$, which is dominant to orange $\left(y^{O} y^{O}\right)$, which is dominant to salmon yellow $(y y)$. Canary yellow $(C C)$ is dominant to non-canary yellow ( $c c)$ and epistatic to (overcomes) the $y$ locus for red-orange-salmon yellow. Coral red is recessive to the white flesh color, which is found in citron. Canary yellow flesh color was introduced to the United States from Chinese cultivars and may be higher in citruline and arginine than red-fleshed cultivars.

Watermelon cultivars are categorized by fruit size, shape, and rind pattern (Wehner et al., 2001). Fruit sizes are termed mini (less than $4.0 \mathrm{~kg}$ ), icebox (4.0 to $5.5 \mathrm{~kg})$, small $(5.5$ 


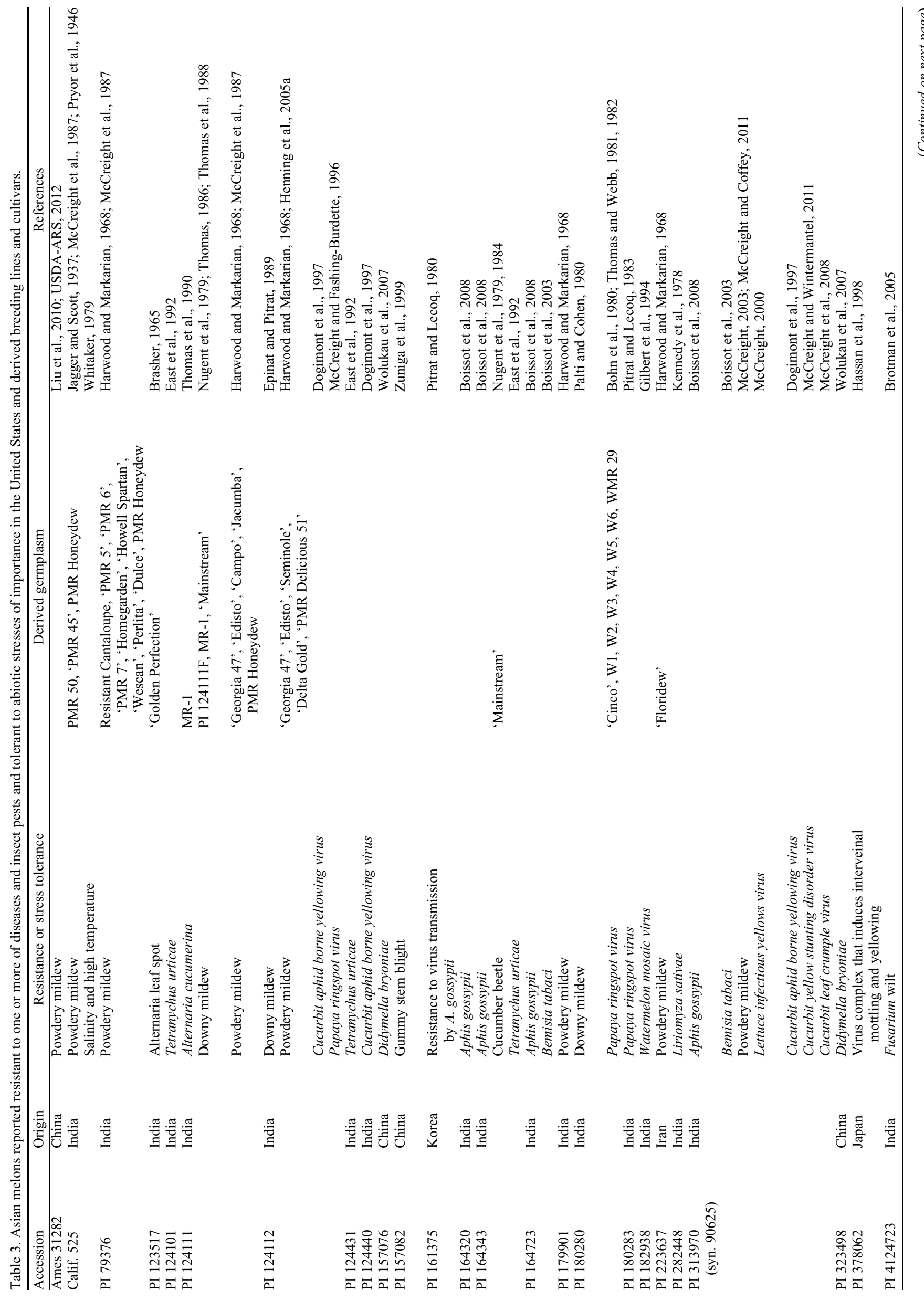

HortScience Vol. 48(9) September 2013 
to $8.0 \mathrm{~kg}$ ), medium ( 8.0 to $11 \mathrm{~kg}$ ), large ( 11 to $14.5 \mathrm{~kg}$ ), and giant (greater than $14.5 \mathrm{~kg}$ ).

Mini watermelon cultivars were developed for home garden use in the northern United States. New Hampshire Midget was a popular mini cultivar that was developed in 1951 by the University of New Hampshire using several cultivars that included Favorite Honey. Mini watermelons became popular for commercial growers with the introduction of the mini seedless type. That type is especially popular for off-season (winter) production as well as for sales to those with small families.

Cultivars used for breeding mini seedless cultivars included cultivars from China and Japan. Asian cultivars have high fruit quality and small fruit size and were important for development of the inbred parents for the production of mini seedless hybrids. The advantage of the Asian cultivars was their higher quality compared with cultivars such as 'New Hampshire Midget', particularly rind toughness and flesh sweetness.

Hybrid watermelon seed production has been improved using male-sterile mutants, some of which were obtained from China (Guner and Wehner, 2004a). Male sterility is used to keep seed costs low by reducing labor inputs. Hybrid production with the Chinese male-sterile genes can be done using alternating rows of the male-sterile (female) parent and the male-fertile (male) parent with honeybees or other insect pollinators to move the pollen from the male parent rows to the female parent rows.

The gynoecious mutant, $g y$, is an important new trait discovered in China (Jiang and Lin, 2007). The gynoecious mutant offers the same advantage of male sterility of not having to remove the staminate flowers daily from the plants in the seed parent rows to avoid self- and sib-pollination. Also, it may be more useful than genic male sterility because the plants can be self-pollinated late in the season to get $100 \%$ gynoecious plants for seeding in the isolation block for hybrid production.

Papaya ringspot virus-watermelon strain (PRSV-W, formerly Watermelon mosaic virus-1), Watermelon mosaic virus, and Zucchini yellow mosaic virus are the most important viruses of watermelon in the United States (Adlerz and Crall, 1967; Provvidenti, 1993). The major control strategies involve insecticides to eliminate the insect vectors, herbicides to remove alternate hosts, or genetic resistance (Provvidenti, 1993). Accessions with highest resistance to PRSV were PI 244017, PI 244019, PI 482342, PI 482318, and PI 485583 (Guner et al., 2002; Strange et al., 2002). All of the resistant accessions PRSV are from Africa.

Zucchini yellow mosaic is a relatively new disease of watermelon, caused by the potyvirus, Zucchini yellow mosaic virus (Guner and Wehner, 2004b). Resistant accessions have been identified in the watermelon germplasm collection maintained by the USDA. Resistant accessions include PI 386015, PI 386016, PI 386018, and PI 386019 from Iran as well as PI 537277 from Pakistan. These five Asian accessions are from the related species C. colocynthis, which is interfertile with watermelon (C. lanatus).

Watermelon is one of the most resistant cucurbit species to powdery mildew (Podosphaera xanthii, formerly Sphaerotheca fuliginea). However, there are a few regions of the world where powdery mildew is a problem on watermelon. For example, watermelons grown in southern India are affected with the disease, but not in northern India. In southern India, 'Arka Manik' is resistant to powdery mildew. The $\mathrm{pm}$ gene causes susceptibility to the disease, but most cultivars have the resistance allele, Pm (Guner and Wehner, 2004a). Powdery mildew is becoming more of a problem in the United States, especially in the western states, and has been reported in the southeastern states. Accessions with resistance have been identified in the watermelon germplasm collection maintained by the USDA. Two $C$. colocynthis accessions from Iran are highly resistant: PI 386015 and PI 386024 (Davis et al., 2007; Tetteh et al., 2010).

Watermelon is one of the most susceptible of the cucurbit species to gummy stem blight caused by Didymella bryoniae (Gusmini et al., 2005). The disease occurs throughout the southern United States, particularly the Southeast. Field and greenhouse tests for resistance have been developed, but it can be difficult to get reproducible results. The USDA collection of PI accessions has been screened for gummy stem blight resistance by several teams of researchers. Some accessions have resistance to the disease, including PI 211915 from Iran, an accession of C. lanatus.

\section{BITTER GOURD}

Bitter gourd is an important vegetable domesticated in eastern India and southern China (Walters and Decker-Walters, 1988). It is cultivated commercially in Asia on $\approx 340,000$ ha annually (Arvind Kapur, Rasi Seeds, personal communication). It is also cultivated in smaller volumes in the southern United States and Australia (Northern Territory, Queensland, New South Wales, Victoria) using Asian cultivars. Asian varieties are also grown in Ghana for fresh fruit export to European countries for their Asian communities. Its cultivation is gaining ground in Zambia, Congo, and Madagascar for local consumption and export. Nearly $60 \%$ of the bitter gourd production area is devoted to open-pollinated varieties (Ajay Dayal, Rasi Seeds, personal communication). Seed companies release numerous hybrid varieties each year in Asia that are more consistent for quality and yield than open-pollinated cultivars. Four hundred thirty-four bitter gourd accessions that originated from more than 15 countries are housed in the genebank of AVRDC-The World Vegetable Center, Taiwan.

Consumers prefer bitter gourd fruit at a physiologically immature or unripe stage and 


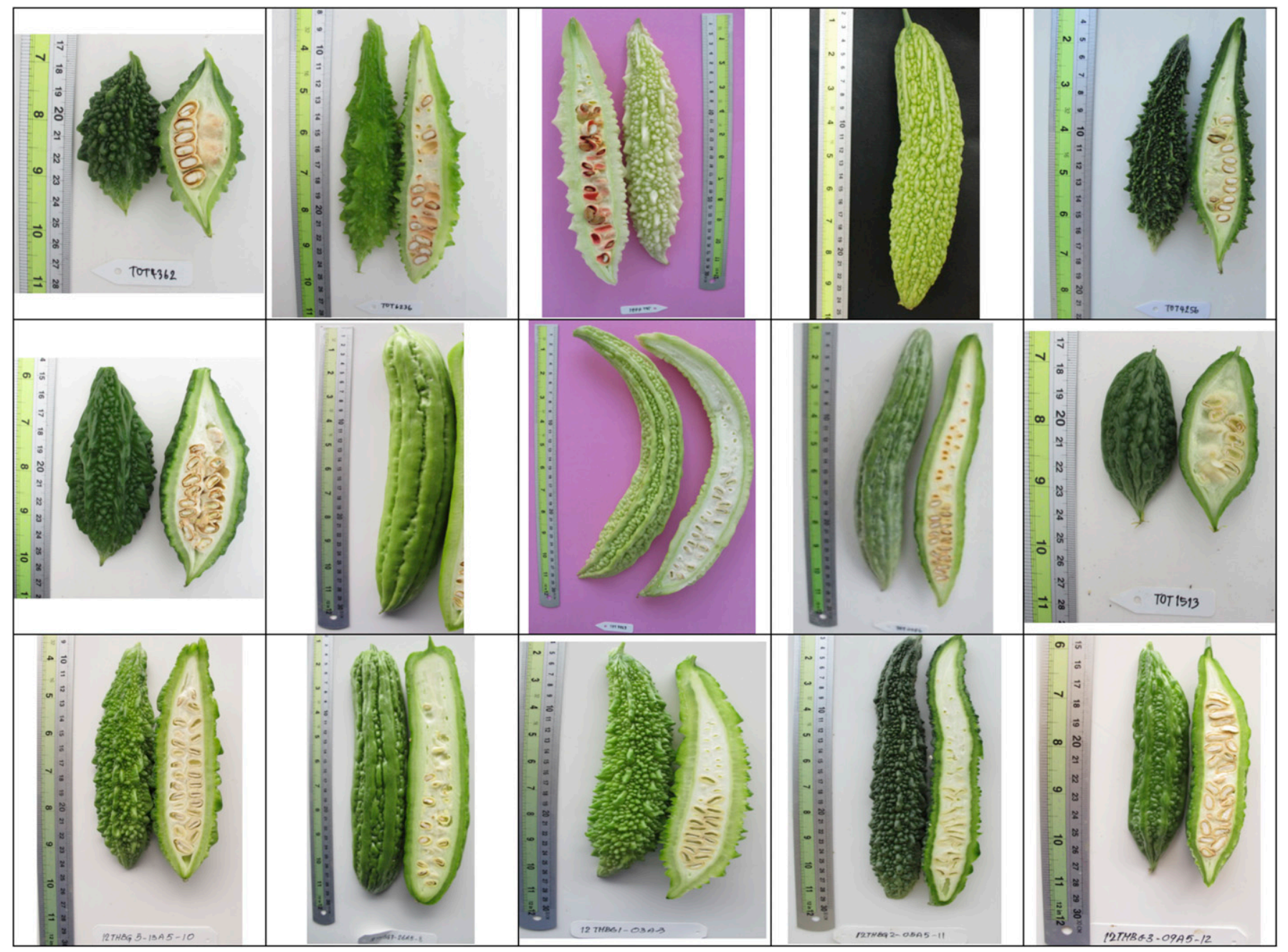

Fig. 6. Bitter gourd fruit type variation. Photos courtesy of Ms. Supunsa Phethin.

it is correlated with fresh bright appearance of fruits and immature creamy white seedcoat. Consumers display a wide range of preference for fruit color, shape, skin pattern and size, which varies between and within countries. Fruit color ranges from white or cream to light green to dark green and the various shapes include cylindrical, elliptical, spindle, and conical. Fruits of different varieties may have regular or irregular longitudinal ridges and warty skin. On the basis of these fruit types, nearly 20 market types of bitter gourd exist in Asia (Fig. 6) and half of these are grown in south Asia alone (India, China, Nepal, Bangladesh, Sri Lanka).

Asian consumers cook bitter gourd fruits with other vegetables, stuffed or stir-fried, or add them to soups to produce a slightly bitter flavor. Fruits are blanched, parboiled, or soaked in saltwater before cooking to reduce the bitter taste. Flowers and young shoots are also used in various Asian dishes to add flavor. Bitter gourd tea prepared from dried fruit is a popular health drink in Japan and some other Asian countries. In many African countries, the fruit is used as a purgative and vermifuge, and leaves are boiled in water and taken to treat diarrhea and dysentery (Ross, 2003).
Bitter gourd abounds in nutrients such as beta-carotene, vitamin $\mathrm{C}$, folic acid, magnesium, phosphorus, and potassium (Yuwai et al., 1991). Recently the species has been considered as one of five crops, along with scuba rice, mung beans, disease-resistant bananas, and drought-hardy maize that have the potential to save the world (Rose, 2012). Saponins, momordicosides $\mathrm{K}$ and $\mathrm{L}$, and momordicines I and II cause bitter taste of fruit (Harinantenaina et al., 2006; Yasuda et al., 1984). Bitter gourd has medicinal properties in addition to its use as a vegetable and is often used in folk medicine to treat Type 2 diabetes, a rapidly spreading noncommunicative disease that afflicts 346 million people worldwide with $80 \%$ of these people living in low-income and middleincome countries (WHO, 2013). Bitter gourd fruit contain compounds (saponins, lipids) linked to anti-diabetic effects (Klomann et al., 2010). Mass evaluation of leading commercial hybrids and genebank accessions of bitter gourd for these bioactive compounds and other micronutrients is being pursued at the AVRDC-The World Vegetable Center, which may help to identify bitter gourd germplasm with increased phytomedicine/ phytonutrient content. In addition, bitter gourd plants contain a range of bioactive compounds with potential to control many other diseases. For example, momordin I is reported to be tumor-protective, momordicines I and II act as anti-microbials, and acylglucosylsterols as having anti-mutagenic, chitinase bacteriostatic effects (Nerukar et al., 2008; Njoroge and van Luijk, 2004; Yuwai et al., 1991). Preliminary studies (in vitro as well as in vivo) using bitter gourd fruit extract and its various purified fractions including MAP 30 have proven anticancer activity (Basch et al., 2003; Battelli et al., 1996; Ganguly et al., 2000; Licastro et al., 1980; Ng et al., 1994; Sun et al., 2001).

\section{ROOTSTOCKS AND GRAFTING}

Cucurbit grafting originated in Asia (Japan, Korea) in the 1920 s as an effective tool to manage soilborne fusarium wilt (Fusarium spp.) on watermelon (Davis et al., 2008) and is now common in Japan, Korea, and China for watermelon, cucumber, melon, and bitter gourd (Table 4). This horticultural practice was introduced to Western countries in the early 1990s and is now rapidly expanding worldwide. Japan and Korea are the major exporters of grafted cucurbit seedlings (Lee 
Table 4. Use of grafted cucurbits in Asia (Lee et al., 2010).

\begin{tabular}{|c|c|c|c|c|c|c|c|c|c|c|c|c|}
\hline \multirow[b]{3}{*}{ Country } & \multicolumn{3}{|c|}{ Watermelon } & \multicolumn{3}{|c|}{ Cucumber } & \multicolumn{3}{|c|}{ Melon } & \multicolumn{3}{|c|}{ Bitter gourd } \\
\hline & & Grafted & & & Grafted & & & Graftec & & & Grafte & \\
\hline & Area (ha) & $(\%)$ & Rootstock $^{\mathrm{z}}$ & Area (ha) & $(\%)$ & Rootstock ${ }^{\mathrm{z}}$ & Area (ha) & $(\%)$ & Rootstock $^{\mathrm{z}}$ & Area (ha) & $(\%)$ & Rootstock $^{\mathrm{z}}$ \\
\hline Japan & 13,000 & 92 & Ls Cl & 12,800 & 75 & $\mathrm{Cmm} \mathrm{Cf}$ & 10,500 & 30 & $\mathrm{Cmm} \mathrm{Cm}$ & - & - & - \\
\hline Korea & 20,756 & 95 & Ls Cmm & 5,630 & 75 & $\mathrm{Cmm} \mathrm{Cf}$ & 6,607 & 90 & $\mathrm{Cmm}$ & - & - & - \\
\hline China & $2,162,456$ & 20 & Ls Cl & $1,702,77$ & 30 & $\mathrm{Cm} \mathrm{Sa} \mathrm{Cf}$ & 570,874 & 5 & $\mathrm{Cm} \mathrm{Cmm} \mathrm{Cl}$ & 200,000 & 2 & $\mathrm{Lc}$ \\
\hline Taiwan & 13,431 & 35 & Cmm Ls & 2,666 & 11 & - & 6,441 & 0.1 & - & 1,802 & 30 & $\mathrm{La} \mathrm{Cm}$ \\
\hline
\end{tabular}

${ }^{\mathrm{z}} \mathrm{Cf}=$ Cucurbita ficifolia $; \mathrm{Cm}=$ Cucurbita moschata $; \mathrm{Cmm}=$ Cucurbita maxima $\times$ C. moschata $; \mathrm{Cl}=$ Citrullus lanatus; La $=$ Luffa aegyptica $;$ Lc $=$ Luffa

cylindrica; $\mathrm{Ls}=$ Lagenaria siceraria $; \mathrm{Sa}=$ Sicyos angulatus.

et al., 2010). In addition to control of soilborne diseases, use of rootstocks has resulted in improved plant vigor through efficient use of nutrients and water, cold tolerance, heat tolerance, and tolerance to salinity and wet soil conditions (Lee et al., 2010).

The main rootstocks for watermelon for control of fusarium wilt are bottle gourd (Lagenaria siceraria Mol. standl.), interspecific hybrids $C$. maxima $\times C$. moschata, and wild watermelon (C. lanatus var. citroides) (Davis et al., 2008). Interspecific Cucurbita hybrid rootstocks also provide heat and drought tolerance but often result in the loss of watermelon flesh quality, which has been attributed to changes in flesh maturation (King et al., 2010). Interspecific Cucurbita hybrid rootstocks are powdery mildew-susceptible.

Bottle gourd is the main rootstock for watermelon grafting in Japan (Oda, 2002). Multiple disease-resistant accessions of bottle gourd of Asian origin will be helpful in breeding multiple disease-resistant rootstocks. Bottle gourd accession PI 271353, which was collected in India, was reported to be resistant to powdery mildew and Zucchini yellow mosaic virus (Kousik et al., 2008).

The common rootstock for melon grafting, a C. moschata $\times$ C. maxima hybrid, provides partial protection to soilborne disease and abiotic stresses but reduces fruit quality.

Fusarium wilt-resistant melon rootstocks give complete protection to susceptible melon scions without adversely affecting fruit quality or yield. Melon rootstocks resistant to root knot nematodes (Meloidogyne spp.) are not available commercially, but a couple of accessions of Indian snapmelon (Momordica group) and "wild melon" have been reported resistant to nematodes (Dhillon et al., 2007; Roy et al., 2012). Indian melon landraces (Momordica and Acidulus groups, and "wild") should be evaluated for vigorous root growth, resistance to soilborne pathogens (Fusarium spp., Monosporascus spp.) and nematodes (Meloidogyne spp.), and suitability for potential use as rootstocks as well as for breeding resistant melon cultivars.

Cucumber grafting is practiced to increase cold tolerance and resistance to fusarium wilt. Specific genotypes of C. moschata that cause bloomless (wax-free) cucumber fruit are used as cucumber rootstocks in Japan. These bloomless fruits have a distinct appearance and enhanced shelf life (Sakata et al., 2008).
Cucurbit rootstock breeding research work is primarily undertaken in China, Japan, and Korea, mostly by private industry. The focus is to improve disease resistance and vigor, and there is a continuous need to develop/select suitable rootstock/scion combinations with high fruit quality traits such as improved fruit appearance and texture and enhanced concentration of health-promoting compounds.

\section{Literature Cited}

Adlerz, W.C. and J.M. Crall. 1967. Epidemiology of control of watermelon mosaic virus. Florida Agr. Exp. Sta. Annu. Rept. 403.

Akashi, Y., N. Fukuda, T. Wako, M. Masuda, and K. Kato. 2002. Genetic variation and phylogenetic relationships in East and South Asian melons, Cucumis melo L., based on the analysis of five isozymes. Euphytica 125:385-396.

Anon. 2003. Xinjiang Hami melon. 4 Feb. 2013. $<$ http://www.chinaculture.org/gb/en_aboutchina/ 2003-09/24/content_22024.htm>

Anon. 2008. Türkmen gawunlary atlas, 3-nji nesir (Turkmen melons. Atlas, 3rd ed.). Food Industry Association of Turkmenistan, Ashgabat.

Anon. 2010. California-grown Korean melons and other delicious Asian fruits and vegetables. 4 Feb. 2013. <http://www.jhfarms.com>.

Anon. 2012a. Honey Kiss. 4 Feb. 2013. <http:// www.sandstonemelons.com/honeykiss.php>.

Anon. 2012b. Sprite melons. 4 Feb. 2013. <http:// www.ncagr.gov/freshconnect/shipperdirectory/ spritemelons.htm $>$.

Anon. 2012c. How to eat a Korean melon. 4 Feb. 2013. <http://www.ehow.com/how_8261210_ eat-korean-melon.html $>$.

Anon. 2012d. Specialty melons. University of Kentucky-College of Agriculture Crop Diversification \& Biofuel Research \& Education, Crop Profiles. 4 Feb. 2013. <http://www.uky. edu/Ag/NewCrops/introsheets/specialty.pdf $>$.

Basch, E., S. Gabardi, and C. Ulbricht. 2003. Bitter melon (Momordica charantia): A review of efficacy and safety. J. Health and Systemic Pharmacology 65:356-359.

Battelli, M.G., L. Polito, A. Bolognesi, L. Lafleur, Y. Fradet, and F. Stripe. 1996. Toxicity of ribosome-inactivating proteins-containing immunotoxins to a human bladder carcinoma cell line. Intl. J. Cancer 68:485-490.

Block, C.C. and K.R. Reitsma. 2005. Powdery mildew resistance in the U.S. National Plant Germplasm System cucumber collection. HortScience 40:416-420.

Bohn, G.W., A.N. Kishaba, and J.D. McCreight. 1980. WMR 29 muskmelon breeding line. HortScience 15:539-540.

Boissot, N., D. Lafortune, C. Pavis, and N. Sauvion. 2003. Field resistance to Bemisia tabaci in Cucumis melo. HortScience 38:77-80.

Boissot, N., P. Mistral, V. Chareyron, C. Dogimont, and M. Pitrat. 2008. A new view on aphid resistance in melon: The role of Aphis gossypii variability, p. 163-171. In: Pitrat, M. (ed.). Cucurbitaceae 2008, IXth EUCARPIA Meeting on Genetics and Breeding of Cucurbitaceae, INRA, Avignon, France.

Brasher, E.P. 1965. The Golden Perfection cantaloupe (muskmelon). Univ. Delaware Agric. Expt. Sta. Bul. 355.

Brotman, Y., I. Kovalski, C. Dogimont, M. Pitrat, V. Portnoy, N. Katzir, and R. Perl-Treves. 2005. Molecular markers linked to Papaya ring spot virus resistance and fusarium race 2 resistance in melon. Theor. Appl. Genet. 110:337-345.

Burger, Y., H.S. Paris, R. Cohen, N. Katzir, Y. Tadmor, E. Lewinsohn, and A.A. Schaffer. 2010. Genetic diversity of Cucumis melo, p. 165-198. In: Janick, J. (ed.). Horticultural reviews. Wiley-Blackwell, New York.

Chen, J., J. Staub, C. Qian, J. Jiang, X. Luo, and F. Zhuang. 2003. Reproduction and cytogenetic characterization of interspecific hybrids derived from Cucumis hystrix Chakr. $\times$ Cucumis sativus L. Theor. Appl. Genet. 106:688-695.

Chen, J.F., S. Isshiki, Y. Tashiro, and S. Miyazaki. 1995. Studies on a wild cucumber from China (Cucumis hystrix Chakr.). I. Genetic distances between $C$. hystrix and two cultivated Cucumis species (C. sativus $\mathrm{L}$. and C. melo $\mathrm{L}$.) based on isozyme analysis. J. Jpn. Soc. Hort. Sci. 64: 264-265.

Chen, J.F. and J.H. Kirkbride. 2000. A new synthetic species of Cucumis (Cucurbitaceae) from interspecific hybridization and chromosome doubling. Brittonia 52:315-319.

Chen, J.F., J.E. Staub, Y. Tashiro, S. Isshiki, and S. Miyazaki. 1997. Successful interspecific hybridization between Cucumis sativus $\mathrm{L}$. and C. hystrix Chakr. Euphytica 96:413-419.

Chung, S.M., J.E. Staub, and J.F. Chen. 2006. Molecular phylogeny of Cucumis species as revealed by consensus chloroplast SSR marker length and sequence variation. Genome 49: 219-229.

Crosby, K., J. Jifon, and D. Leskovar. 2007. 'Pacal' orange-casaba, and 'Chujuc' Western-Shipper cantaloupe: Two new melon cultivars from the Texas Agricultural Experiment Station. HortScience 42:1013 [abstr.].

Crosby, K.M., J.L. Jifon, and D.I. Leskovar. 2008 'Chujuc', a new powdery mildew-resistant U.S. western-shipper melon with high sugar and $\beta$-carotene content. HortScience 43:1904-1906.

Dane, F., D.W. Denna, and T. Tsuchiya. 1980. Evolutionary studies of wild species in the genus Cucumis. Z. Pflanzenzücht 85:89-109.

Davis, A.R., A. Levi, A. Tetteh, T. Wehner, V. Russo, and M. Pitrat. 2007. Evaluation of watermelon and related species for resistance to race $1 \mathrm{~W}$ powdery mildew. J. Amer. Soc. Hort. Sci. 132: 790-795.

Davis, A.R., P. Perkins-Veazie, Y. Sakata, S. Lopez-Galavza, J.V. Maroto, S.G. Lee, Y.C. Huh, Z. Sun, A. Migual, S.R. King, R. Cohen, and J.M. Lee. 2008. Cucurbit grafting. Crit. Rev. Plant Sci. 27:50-74. 
Davis, R.M. 1970. Vein tracts not sutures in cantaloupe. HortScience 5:86.

Day, P.R. 1997. Biodiversity and the equitable use of the World's genetic resources, p. 3-12. In: Hoagland, K.E. and A.Y. Rossman (eds.). Global genetic resources: Access, ownership, and intellectual property rights. Assn. Systematics Collections, Washington, DC.

Deakin, J.R., G.W. Bohn, and T.W. Whitaker. 1971. Interspecific hybridization in Cucumis. Econ. Bot. 25:195-211.

Decker-Walters, D.S., S.M. Chung, J.E. Staub, H.D. Quemada, and A.I. López-Sesé. 2002. The origin and genetic affinities of wild populations of melon (Cucumis melo, Cucurbitaceae) in North America. Plant Syst. Evol. 233:183-197.

Delannay, I.Y., J.E. Staub, and J.F. Chen. 2010. Backcross introgression of the Cucumis hystrix Chakr. Genome increases genetic diversity in U.S. processing cucumber (Cucumis sativus L.). J. Amer. Soc. Hort. Sci. 135:351-361.

Dhillon, N.P.S., A.J. Monforte, M. Pitrat, S. Pandey, P.K. Singh, K.R. Reitsma, J. GarciaMas, A. Sharma, and J.D. McCreight. 2012. Melon landraces of India: Contributions and importance, p. 85-150. In: Janick, J. (ed.). Plant breeding rev. John Wiley \& Sons, Inc., New York, NY.

Dhillon, N.P.S., R. Ranjana, K. Singh, I. Eduardo, A.J. Monforte, M. Pitrat, N.K. Dhillon, and P.P. Singh. 2007. Diversity among landraces of Indian snapmelon (Cucumis melo var. momordica). Genet. Resources Crop Evol. 54:1267-1283.

Dhillon, N.P.S., J. Singh, M. Fergany, A.J. Monforte, and A.K. Sureja. 2009. Phenotypic and molecular diversity among landraces of snapmelon (Cucumis melo var. momordica) adapted to the hot and humid tropics of eastern India. Plant Genetic Resources 7:291-300.

Dijkhuizen, A., W.C. Kennard, M.J. Havey, and J.E. Staub. 1996. RFLP variability and genetic relationships in cultivated cucumber. Euphytica 90:79-89.

Dogimont, C., A. Bussemakers, J. Martin, S. Slama, H. Lecoq, and M. Pitrat. 1997. Two complementary recessive genes conferring resistance to Cucurbit aphid borne yellows luteovirus in an Indian melon line (Cucumis melo L.). Euphytica 96:391-395.

East, D.A., J.V. Edelson, E.L. Cox, and M.K. Harris. 1992. Evaluation of screening methods and search for resistance in muskmelon, $\mathrm{Cucu}$ mis melo L, to the twospotted spider mite, Tetranychus urticae Koch. Crop Prot. 11:39-44.

Epinat, C. and M. Pitrat. 1989. Inheritance of resistance of three lines of muskmelon ( $\mathrm{CuCu}$ mis melo) to downy mildew (Pseudoperonospora cubensis), p. 133-135. In: Thomas, C.E. (ed.). Proc. Cucurbitaceae 89, Evaluation and Enhancement of Cucurbit Germplasm, 29 Nov. to 2 Dec. 1989, Charleston, SC.

Escribano, S., A. Lázaro, H.E. Cuevas, J.E. Staub, A.I. López-Sesé, and J.E. Staub. 2012. Spanish melons (Cucumis melo L.) of the Madrid provenance: A unique germplasm reservoir. Genet. Resources Crop Evol. 59:359-373.

Esquinas-Alcazar, J.T. 1977. Alloenzyme variation and relationships in the genus Cucumis. $\mathrm{PhD}$ diss., Univ. of California, Davis, CA.

Esquinas-Alcazar, J.T. 1981. Alloenzyme variation and relationships among Spanish land-races of Cucumis melo L. Kulturpflanze 29:337-352.

Esquinas-Alcazar, J.T. and P.J. Gulick. 1983. Genetic resources of Cucurbitaceae-A global report. International Board for Plant Genetic Resources, Rome, Italy.
Fan, Z., M.D. Robbins, and J.E. Staub. 2006. Population development by phenotypic selection with subsequent marker-assisted selection for line extraction in cucumber (Cucumis sativus L.). Theor. Appl. Genet. 112:843-855.

Fergany, M., B. Kaur, A.J. Monforte, M. Pitrat, C. Rys, H. Lecoq, N.P.S. Dhillon, and S.S. Dhaliwal. 2011. Variation in melon (Cucumis melo) landraces adapted to the humid tropics of southern India. Genet. Resources Crop Evol. 55:225-243.

Ganguly, C., S. De, and S. das. 2000. Prevention of carcinogen-induced mouse skin papilloma by whole fruit aqueous extract of Momordica charantia. Eur. J. Cancer Prev. 9:283-288.

Garcia-Mas, J., A. Benjak, W. Sanseverino, M Bourgeois, G. Mir, V.M. González, E. Hénaff, F. Câmara, L. Cozzuto, E. Lowy, T. Alioto, S Capella-Gutiérrez, J. Blanca, J. Cañizares, P. Ziarsolo, D. Gonzalez-Ibeas, L. RodríguezMoreno, M. Droege, L. Du, M. AlvarezTejado, B. Lorente-Galdos, M. Melé, L. Yang, Y. Weng, A. Navarro, T. Marques-Bonet, M.A. Aranda, F. Nuez, B. Picó, T. Gabaldón, G. Roma, R. Guigó, J.M. Casacuberta, P. Arús, and P. Puigdomènech. 2012. The genome of melon (Cucumis melo L.). Proc. Natl. Acad. Sci. USA 109:11872-11877.

Gathman, A.C. and W.P. Bemis. 1990. Domestication of buffalo gourd, Cucurbita foetidissima, p. 335-348. In: Bates, D.M., R.W. Robinson, and C. Jeffrey (eds.). Biology and utilization of the cucurbitaceae. Comstock Publishing Associates, Ithaca, NY.

Gilbert, R.Z., M.M. Kyle, H.M. Munger, and S.M. Gray. 1994. Inheritance of resistance to watermelon mosaic virus in Cucumis melo $\mathrm{L}$. HortScience 29:107-110.

Goldman, A. and V. Schrager. 2002. Melons for the passionate grower. Artisan, New York, NY.

Guner, N., E.B. Strange, T.C. Wehner, and Z. Pesic-VanEsbroeck. 2002. Papaya ringspot virus type- $\mathrm{W}$ resistance in watermelon, p. 238 246. In: Maynard, D.N. (ed.). Proc. Cucurbitaceae 2002. ASHS Press, Alexandria, VA.

Guner, N. and T.C. Wehner. 2004a. The genes of watermelon. HortScience 39:1175-1182.

Guner, N. and T.C. Wehner. 2004b. Resistance to a severe strain of Zucchini yellow mosaic virus in watermelon, p. 223-230. In: Lebeda, A. and H.S. Paris (eds.). Progress in cucurbit genetics and breeding research. Proc. of Cucurbitaceae 2004, 8th EUCARPIA meeting, Olomouc, Czech Republic, 12-17 July 2004. Palacky University, Olomouc.

Gusmini, G., R. Song, and T.C. Wehner. 2005. New sources of resistance to gummy stem blight in watermelon. Crop Sci. 45:582-588.

Harinantenaina, L., M. Tanaka, S. Takaoka, M. Oda, O. Mogami, M. Uchida, and Y. Asakawa. 2006. Momordica charantia constituents and antidiabetic screening of the isolated major compounds. Chem. Pharmaceutical Bul. 54: 1017-1021.

Harwood, R.R. and D. Markarian. 1968. A genetic survey of resistance to powdery mildew in muskmelon. J. Hered. 59:213-217.

Hassan, A.A., M.M. Merghany, K.A. Abdel-Ati, and A.M. Abdel-Salam. 1998. Inheritance of resistance to interveinal mottling and yellowing disease in cucurbits. Egyptian J. Hort. 25: 209-224.

Henning, M.J., H.M. Munger, and M.M. Jahn. 2005a. 'PMR Delicious 51': An improved open-pollinated melon with resistance to powdery mildew. HortScience 40:261-262.

Henning, M.J., H.M. Munger, and M.M. Jahn. 2005b. 'Hannah's Choice $F_{1}$ ': A new muskmelon hybrid with resistance to powdery mildew, fusarium race 2 , and potyviruses. HortScience 40:492-493.

Horejsi, T. and J.E. Staub. 1999. Genetic variation in cucumber (Cucumis sativus L.) as assessed by random amplified polymorphic DNA. Genet. Resources Crop Evol. 46:337-350.

Horst, E.K. and R.L. Lower. 1978. Cucumis hardwickii: A source of germplasm for the cucumber breeder. Cucurbit Genetics Coop. Rpt. 1:5.

Jacks, T.J., T.P. Hensarling, and L.Y. Yatsu. 1972. Cucurbit seeds: I. Characterizations and uses of oils and proteins. A review. Econ. Bot. 26: 135-141.

Jagger, I.C. and G.W. Scott. 1937. Development of powdery mildew resistant cantaloup No. 45 . USDA Circ. 441:6.

Janick, J., H.S. Paris, and D.C. Parrish. 2007. The cucurbits of Mediterranean antiquity: Identification of taxa from ancient images and descriptions. Ann. Bot. (Lond.) 100:14411457.

Jeffrey, C. 1980. A review of the Cucurbitaceae. Bot. J. Linn. Soc. 81:233-247.

Jensen, B.D. 2012. African watermelons and their uses, p. 264-272. In: Sari, N., I. Solmaz, and V. Aras (eds.). Cucurbitaceae 2012, Proc. of the Xth EUCARPIA meeting on genetics and breeding of Cucurbitaceae, Antalya (Turkey), 15-18 Oct. 2012.

Jiang, X.T. and D. Lin. 2007. Discovery of watermelon gynoecious gene gy. Acta Hort. Sinica 34:141-142.

Kaçar, Y.A., O. Simsek, I. Solmaz, N. Sari, and Y.Y. Mendi. 2012. Genetic diversity among melon accessions (Cucumis melo) from Turkey based on SSR markers. Genet. Mol. Res. 11:4622-4631.

Kennedy, G.G., G.W. Bohn, A.K. Stoner, and R.E. Webb. 1978. Leafminer resistance in muskmelon. J. Amer. Soc. Hort. Sci. 103:571574.

King, S.R., A.R. Davis, X. Zhang, and K. Crosby. 2010. Genetics, breeding and selection of rootstocks for Solanaceae and Cucurbitaceae. Sci. Hort. 127:106-111.

Kirkbride, J.H., Jr. 1993. Biosystematic monograph of the genus Cucumis (Cucurbitaceae). Parkway Publishers, Boone, NC.

Kishaba, A.N., S. Castle, D.L. Coudriet, J.D. McCreight, and G.W. Bohn. 1992. Virus transmission by Aphis gossypii Glover to aphidresistant and susceptible muskmelons. J. Amer. Soc. Hort. Sci. 117:248-254.

Kishaba, A.N., S.J. Castle, D.L. Coudriet, J.D. McCreight, and G.W. Bohn. 1998. Resistance to western spotted and striped cucumber beetle in melon, p. 101-105. In: McCreight, J.D. (ed.). Cucurbitaceae '98: Evaluation and enhancement of cucurbit germplasm, 30 Nov. to 4 Dec. 1998. ASHS Press, Alexandria, VA.

Klomann, S.D., A.S. Mueller, J. Pallauf, and M.B. Krawinkel. 2010. Antidiabetic effects of bitter gourd extracts in insulin resistant $\mathrm{db} / \mathrm{db}$ mice. Brit. J. Nutr. 104:1613-1620.

Kousik, C.S., A. Levi, K. Ling, and W.P. Wechter. 2008. Potential sources of resistance to cucurbit powdery mildew in U.S. plant introductions of bottle gourd. HortScience 43: 1359-1364

Lee, J.M., C. Kubota, S.J. Tsao, Z. Bie, P.H. Echevarria, L. Morra, and M. Oda. 2010 Current status of vegetable grafting: Diffusion, grafting techniques, automation. Scientia Hort. 127:93-105.

Licastro, F., C. Francaschi, L. Barbieri, and F. Stripe. 1980. Toxicity of Momordica charantia lectin and inhibitor for human normal and 
leukaemic lymphocytes. Virchows Arch. B Cell Pathol. Incl. Mol. Pathol. 33:257-265.

Liu, L., Y. Chen, Z. Su, H. Zhang, and W. Zhu. 2010. A sequence-amplified characterized region marker for a single, dominant gene in melon PI 134198 that confers resistance to a unique race of Podosphaera xanthii in China. HortScience 45:1407-1410.

Luan, F., I. Delannay, and J.E. Staub. 2008. Chinese melon (Cucumis melo L.) diversity analyses provide strategies for germplasm curation, genetic improvement, and evidentiary support of domestication patterns. Euphytica 164:445-461.

Mavlyanova, R., A. Rustamov, R. Khakimov, A. Khakimov, M. Turdieva, and S. Padulosi. 2005a. Melons of Uzbekistan. International Plant Genetic Resource Institute's, Sub-regional Office for Central Asia. Tashkent, Uzbekistan. 4 Feb. 2013. <http://www.bioversityinternational. org/index.php?id=19\&user_bioversitypublications_ pi1\%5BshowUid\%5D=2994>.

Mavlyanova, R.F., F.K. Abdullaev, P. Khodjiev, D.E. Zaurov, T.J. Molnar, J.C. Goffreda, T.J. Orton, and C.R. Funk. 2005b. Plant genetic resources and scientific activities of the Uzbek Research Institute of Plant Industry. HortScience 40:10-14.

McCreight, J.D. 2000. Inheritance of resistance to Lettuce infectious yellows virus in melon. HortScience 35:1118-1120.

McCreight, J.D. 2003. Genes for resistance to powdery mildew races 1 and 2 U.S. in melon PI 313970. HortScience 38:591-594.

McCreight, J.D. 2004. Notes on the change of the causal species of cucurbit powdery mildew in the U.S. Cucurbit Genet. Coop. Rpt. 27:8-23.

McCreight, J.D. (ed.). 2007. Vegetable cultivar descriptions for North America. Melon, lists 1-26 combined. 4 Feb. 2013. <http://cuke.hort.ncsu. edu/cucurbit/wehner/vegcult/melon.html $>$.

McCreight, J.D. and G.W. Bohn. 1979. Descriptions, genetics, and independent assortment of red stem and pale in muskmelon (Cucumis melo L.). J. Amer. Soc. Hort. Sci. 104:721-723.

McCreight, J.D., G.W. Bohn, and T.W. Whitaker. 1987. PMR Honeydew muskmelon. HortScience 22:177.

McCreight, J.D. and M.D. Coffey. 2011. Inheritance of resistance in melon PI 313970 to cucurbit powdery mildew incited by Podosphaera xanthii race S. HortScience 46:838-840.

McCreight, J.D. and P. Fashing-Burdette. 1996. Resistance of PI 124112 and 'Eldorado-300' melons (Cucumis melo L.) to Papaya ringspot virus watermelon strain, p. 298-301. In: GómezGuillamón, M.L., C. Soria, J. Cuartero, J.A. Torés, and R. Fernández-Muñoz (eds.). Cucurbits towards 2000: Proc. of the VIth Eucarpia Meeting on Cucurbit Genetics and Breeding, 28-30 May 1996, Malaga, Spain.

McCreight, J.D., A.N. Kishaba, and G.W. Bohn. 1984. AR Hale's Best Jumbo, AR 5, and AR Topmark, melon aphid-resistant muskmelon breeding lines. HortScience 19:309-310.

McCreight, J.D., H.-Y. Liu, and T.A. Turini. 2008. Genetic resistance to Cucurbit leaf crumple virus in melon. HortScience 43:122-126.

McCreight, J.D., E. Kokanova, T.C. Wehner, and A.R. Davis. 2010. Turkmenistan melon (Cucumis melo), and watermelon (Citrullus lanatus) germplasm expedition 2008. Cucurbitaceae 2010 Proc., 14-18 Nov. 2010, Charleston, SC.

McCreight, J.D., J.E. Staub, A. López-Sesé, and S.M. Chung. 2004. Isozyme variation in Indian and Chinese melon (Cucumis melo L.) germplasm collections. J. Amer. Soc. Hort. Sci. 129: 811-818.
McCreight, J.D. and W.M. Wintermantel. 2011. Genetic resistance in melon PI 313970 to Cucurbit yellow stunting disorder virus. HortScience 46:1582-1587.

Molinar, R.H. 2012. Evaluation of Central Asian melon varieties in the San Joaquin Valley. J. Amer. Pomol. Soc. 66:122-124.

Nakata, E., J.E. Staub, A. López-Sesé, and N. Katzir. 2005. Genetic diversity in Japanese melon (Cucumis melo L.) as assessed by random amplified polymorphic DNA and simple sequence repeat markers. Genet. Resources Crop Evol. 52:405-419.

Nerukar, P.V., Y.K. Lee, M. Motosue, K. Adeli, and V.R. Nerukar. 2008. Momordica charantia (bitter melon) reduces plasma apolipoprotein B-100 and increases hepatic insulin receptor substrate and phosphoinositide-3 kinase interactions. Br. J. Nutr. 5:1-9.

Ng, T.B., W.K. Liu, S.F. Sze, and H.W. Yeung. 1994. Action of alpha-momorcharin, a ribosome inactivating protein, on cultured tumor cell lines. Gen. Pharmacol. 25:75-77.

Njoroge, G.N. and M.N. van Luijk. 2004. Momordica charantia L. [Internet] Record from Protabase. In: Grubben, G.J.H. and O.A. Denton (eds.). PROTA (Plant Resources of Tropical Africa/ Resources végétales de l'Afrique tropicale), Wageningen, The Netherlands. 3 Feb. 2013. $<$ http://database.prota.org/search.htm $>$.

Nugent, P.E., F.P. Cuthbert, Jr., and J.C. Hoffman. 1984. Two genes for cucumber beetle resistance in muskmelon. J. Amer. Soc. Hort. Sci. 109:756-759.

Nugent, P.E., J.C. Hoffman, and C.F. Andrus. 1979. 'Mainstream' muskmelon. HortScience 14:192.

Oda, M. 2002. Grafting of vegetable crops. Sci. Rep. Agr. Biol. Sci. Osaka Pref. Univ. 53:1-5.

Palti, J. and Y. Cohen. 1980. Downy mildew of cucurbits (Pseudoperonospora cubensis): The fungus and its hosts, distribution, epidemiology and control. Phytoparasitica 8:109-147.

Paris, H.S., Z. Amar, and E. Lev. 2012. Medieval emergence of sweet melons, Cucumis melo (Cucurbitaceae). Ann. Bot. (Lond.) 110:23-33.

Peterson, C.E. 1975. Plant introductions in the improvement of vegetable cultivars. HortScience 10:575-579.

Pitrat, M. 2008. Melon, p. 283-315. In: Prohens, J. and F. Nuez (eds.). Handbook of plant breeding. Springer, New York, NY.

Pitrat, M. 2012. Domestication and diversification of melon, p. 31-39. In: Sari, N., I. Solmaz, and V. Aras (eds.). Cucurbitaceae 2012, Proc. of the Xth EUCARPIA meeting on genetics and breeding of Cucurbitaceae, Antalya (Turkey), 15-18 Oct. 2012.

Pitrat, M., P. Hanelt, and K. Hammer. 2000. Some comments on infraspecific classification of cultivars of melon. Acta Hort. 510:29-36.

Pitrat, M. and H. Lecoq. 1980. Inheritance of resistance to cucumber mosaic virus transmission by Aphis gossypii in Cucumis melo. Phytopathology 70:958-961.

Pitrat, M. and H. Lecoq. 1983. Two alleles for watermelon mosaic virus 1 resistance in muskmelon. Cucurbit Genet. Coop. Rpt. 6:52-53.

Provvidenti, R. 1993. Resistance to viral diseases of vegetables, p. 8-43. In: Kyle, M.M. (ed.). Timber Press, Inc., Portland, OR.

Pryor, D.E., T.W. Whitaker, and G.N. Davis. 1946 The development of powdery mildew resistant cantaloupes. Proc. Amer. Soc. Hort. Sci. 47: 347-356.

Robinson, R.W. and D.S. Decker-Walters. 1997. Cucurbits. CAB International, New York, NY.

Rose, E. 2012. Five foods that will save the world. Reader's Digest, U.K. Edition February:82-88.
Ross, I.A. 2003. Medicinal plants of the world. Chemical constituents, traditional and modern uses. Vol. 1. 2nd Ed. Humana Press, Totowa, NJ.

Roy, A., S.S. Bal, M. Fergany, S. Kaur, H.C. Singh, A.A. Malik, J. Singh, A.J. Monforte, and N.P.S. Dhillon. 2012. Wild melon diversity in India (Punjab State). Genet. Resources Crop Evol. 59:755-767.

Sakata, Y., T. Ohara, and M. Sugiyama. 2008. The history of melon and cucumber grafting in Japan, p. 217-228. In: Prange, R.K. and S.D. Bishop (eds.). Proc. XXVII IHC-S11 Sustainability through Integrated and Organic Horticulture. Acta Hort. (ISHS) 767:217-228.

Schaefer, H., C. Heibl, and S.S. Renner. 2009. Gourds afloat: A dated phylogeny reveals an Asian origin of the gourd family (Cucurbitaceae) and numerous oversea dispersal events. Proc. Royal Soc. Bot. 276:843-851.

Schultheis, J.R. 2006. Cucurbits and their importance in North Carolina, p. 265-271. In: Holmes, G.J. (ed.). Proceedings of Cucurbitaceae 2006. Universal Press, Raleigh, NC.

Sebastian, P., H. Schaefer, I.R.H. Telford, and S.S. Renner. 2010. Cucumber (Cucumis sativus) and melon (C. melo) have numerous wild relatives in Asia and Australia, and the sister species of melon is from Australia. Proc. Natl. Acad. Sci. USA 107:14269-14273.

Secre, S. and J.E. Staub. 1999. Nearly-isogenic cucumber genotypes differing in leaf size and plant habit exhibit differential response to water stress. J. Amer. Soc. Hort. Sci. 124: 358-365.

Shannon, M.C., G.W. Bohn, and J.D. McCreight. 1984. Salt tolerance among muskmelon genotypes during seed emergence and seedling growth. HortScience 19:828-830.

Simon, P.W. and J.P. Navazio. 1997. Early Orange Mass 400, Early Orange Mass 402, and Late Orange Mass 404: High-carotene cucumber germplasm. HortScience 32:144-145.

Staub, J.E. and J. Bacher. 1997. Cucumber as a processed vegetable. In: Processing vegetables: Science and Technology IV. Technomic Publishing Co., Inc., Lancaster, PA.

Staub, J.E., F. Dane, K. Reitsma, G. Fazio, and A. Lopez-Sese. 2002. The formation of test arrays and a core collection in (Cucumis sativus $\mathrm{L}$.) using phenotypic and molecular marker data. J. Amer. Soc. Hort. Sci. 127: $558-567$.

Staub, J.E. and I.Y. Delannay. 2011. USDA, ARS Cucumis hystrix-derived U.S. Processing cucumber inbred backcross line population. HortScience 46:1428-1430.

Staub, J.E., L. Fredrick, and T. Marty. 1987. Electrophoretic variation in cross-compatible wild diploid species of Cucumis. Can. J. Bot. 65:792-798.

Staub, J.E. and R.S. Kupper. 1985. Results of the use of Cucumis sativus var. hardwickii germplasm following backcrossing with Cucumis sativus var. sativus. HortScience 20:436-438.

Staub, J.E., C.E. Peterson, L.K. Crubaugh, and M.J. Palmer. 1992. Cucumber population WI 6383 and derived inbreds WI 5098 and WI 5551. HortScience 27:1340-1341.

Staub, J.E., M.D. Robbins, and T.C. Wehner. 2008 Cucumber, p. 241-282. In: Prohens, J. and F. Nuez (eds.). Vegetables I: Asteraceae, Brassicaceae, Chenopodiaceae, and Cucurbitaceae. Springer, New York, NY.

Staub, J.E., F.C. Serquen, T. Horejsi, and J.F. Chen. 1999. Genetic diversity in cucumber (Cucumis sativus L.): IV. An evaluation of Chinese germplasm. Genet. Resources Crop Evol. 46:297310. 
Staub, J.E., P.W. Simon, and H.E. Cuevas. 2011a. USDA, ARS EOM 402-10 high $\beta$-carotene cucumber. HortScience 46:1426-1427.

Staub, J.E., J.D. McCreight, and J.E. Zalapa. 2011b. USDA 846-1 fractal melon and derived recombinant inbred lines. HortScience 46:14231425 .

Strange, E.B., N. Guner, Z. Pesic-VanEsbroeck, and T.C. Wehner. 2002. Screening the watermelon germplasm collection for resistance to Papaya ringspot virus type-W. Crop Sci. 42:1324-1330.

Sun, Y., P.L. Huang, J.J. Li, Y.Q. Huang, L. Zhang, P.L. Huang, and S. Lee-Huang. 2001. Anti-HIV agent MAP 30 modulates the expression profile of viral and cellular genes for proliferation and apoptosis in AIDS-related lymphoma cells infected with Kaposi's sarcoma-associated virus. Biochem. Biophys. Res. Commun. 287:983-994.

Tapley, W.T., W.D. Enzie, and G.P. van Eseltine. 1937. The vegetables of New York. IV. The cucurbits. Rpt. N.Y. State Agr. Exp. Sta. for the year ending 30 June 1935. Lyon Co., Albany, NY.

Tetteh, A.Y., T.C. Wehner, and A.R. Davis. 2010. Identifying resistance to powdery mildew race $2 \mathrm{~W}$ in the USDA-ARS watermelon germplasm collection. Crop Sci. 50:933-939.

Thomas, C.E. 1986. Downy and powdery mildew resistant muskmelon breeding line MR-1. HortScience 21:329.

Thomas, C.E., Y. Cohen, J.D. McCreight, E.L. Jourdain, and S. Cohen. 1988. Inheritance of resistance to downy mildew in Cucumis melo. Plant Dis. 72:33-35.
Thomas, C.E., J.D. McCreight, and E.L. Jourdain. 1990. Inheritance of resistance to Alternaria cucumerina in Cucumis melo line MR-1. Plant Dis. 74:868-870.

Thomas, C.E. and R.E. Webb. 1981. W1, W3, W4, W5, and W6 multidisease-resistant muskmelon breeding lines. HortScience 16:96.

Thomas, C.E. and R.E. Webb. 1982. 'Cinco' muskmelon. HortScience 17:684-685.

Tzuri, G., V. Portnoy, N. Daube-Mozes, and N. Katzir. 2005. Genetic diversity of melon (Cucumis melo L.) estimated by SSR markers. Cucurbit Genet. Coop. Rpt. 28-29:14-16.

USDA-ARS. 2012. Anes 31282. National Genetic Resources Program. Germplasm Resources Information Network (GRIN). [Online Database] National Germplasm Resources Laboratory, Beltsville, MD. 3 Feb. 2013.<http:// www.ars-grin.gov/cgi-bin/npgs/acc/display.pl? $1898811>$

Walters, T.W. and D.S. Decker-Walters. 1988 Balsampear (Momordica charantia, Cucurbitaceae). Econ. Bot. 42:286-288.

Wehner, T.C. 2008. Watermelon, p. 381-418. In: Prohens, J. and F. Nuez (eds.). Handbook of plant breeding; Vegetables I: Asteraceae, Brassicaceae, Chenopodiaceae, and Cucurbitaceae. Springer Science+Business LLC, New York, NY.

Wehner, T.C., N.V. Shetty, and G.W. Elmstrom. 2001. Breeding and seed production, p. 27-73. In: Maynard, D.N. (ed.). Watermelons. Characteristics, production, and marketing. ASHS Press, Alexandria, VA.
Whitaker, T.W. 1979. The breeding of vegetable crops: Highlights of the past seventy-five years. HortScience 14:359-363.

Whitaker, T.W. and G.W. Bohn. 1956. Muskmelon varieties for the west...south...east. American Vegetable Grower September:10-11.

Whitaker, T.W. and G.N. Davis. 1962. Cucurbits: Botany, cultivation and utilization. Interscience, New York, NY.

WHO. 2013. Fact sheet No. 313. 4 Feb. 2013 $<$ http://www.who.int/mediacentre/factsheets/ fs $312 / \mathrm{en} />$.

Wild, O. 1992. The Silk Road. 4 Feb. 2013. <http:// www.ess.uci.edu/ oliver/silk.html $>$.

Wolukau, J.N., X.-H. Zhou, Y. Li, Y.-B. Zhang, and G.L.-F. Chen. 2007. Resistance to gummy stem blight in melon (Cucumis melo L.) germplasm and inheritance of resistance from Plant Introductions 157076, 420145, and 323498. HortScience 42:215-221.

Yasuda, M., M. Iwamoto, H. Okabe, and T. Yamauchi. 1984. Structures of momordicines I, II and III, the bitter principles in the leaves and vines of Momordica charantia. Chem. Pharmaceutical Bul. 32:2044-2047.

Yuwai, K.E., K.S. Rao, C. Kaluwin, P.G. Jones, and D.E. Rivett. 1991. Chemical composition of Momordica charantia L. fruits. J. Agr. Food Chem. 39:1762-1763.

Zuniga, T.L., J.P. Jantz, T.A. Zitter, and M.K. Jahn. 1999. Monogenic dominant resistance to gummy stem blight in two melon (Cucumis melo) accessions. Plant Dis. 83:1105-1107. 